\title{
Public Space as an Urban Acupuncture: Learning From Bandung, Indonesia
}

\author{
Romi Bramantyo Margono ${ }^{1}$, Siswanti Zuraida ${ }^{2}$ \\ Human Settlement Program, Faculty of Science Engineering, Katholieke Universite Leuven, Leuveun, Belgium \\ Civil Engineering Department, Faculty of Engineering and Design, Institut Teknologi Sains Bandung, Bekasi, \\ Indonesia
}

\begin{abstract}
Bandung is the capital city of West Java, Indonesia. Since colonial era, Bandung has been designed by Dutch colonizer as tuinstad (garden city) to increase quality of life in this city. It is shown by at least five city garden and several plein (square) built from 1885 to 1925. After colony era, Bandung had been developed, it was also affecting the condition of city garden and squares. It became fenced city parks and squares because of maintenance issue and misconception by local municipality. After decades of degradation of parks and squares, in 2013 new mayor of Bandung Ridwan Kamil, has a vision to bring back again the glory of parks. He believes by revitalizing the parks will increase the quality of life in Bandung and also index of happiness. The parks and squares revitalized by giving specific theme, for example: Superhero Park, Photography Park, Pet Park and so forth. The idea is to attract more people come to park. It is also targeted specific community according to the theme to be part of actor that will maintain the park. The aim of this paper is to describe some critical review of the revitalization of parks in Bandung. In comparison with urban acupuncture concept and also review the quality of the parks and squares as public space.
\end{abstract}

Key words: Bandung, urban acupuncture, public space, garden city

\section{INTORDUCTION}

The spread of city park concept was dominantly influenced by the attempt to recover the city against the bad effect of industrialization. It was spread in 19th century in US, England, and Europe continent. Many cities in Sweden, Denmark, and Netherland started to develop city parks to increase quality of the cities. In the end of 19th century, European colonizer introduced the concept of city park in Asia ${ }^{1)}$. Similar condition also happened in Dutch East Indies (Indonesia) as a colony of the Kingdom of the Netherlands. It also can be traced that the concept of park entered Dutch East Indies even since 17th and 18th century.

In beginning of 20th century, Bandung had developed under the influence of the dutch colony. At that time, Bandung is well known as a city with a lot of fertile lands that good for plantation. One of the main commodity is coffee. To support the economic activity, the 
transportation, houses, and many city facilities for Dutch trader (preangerplanters) need to be improved ${ }^{2)}$. Using their economy power, preangerplanters had an essential role in Bandung development ${ }^{3}$. Together with the elite and municipality at that time, they made significant decision for Bandung development according to their European standards.

Afterwards, Bandung had several development, such as adding new transportation lanes, construction of education facilities, improvement of housing and city quality, relocation of European and Chinese cemeteries, building new market, and horse facilities 3).

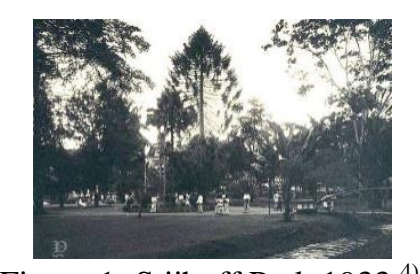

Figure 1: Stijhoff Park $1933^{4)}$

In improvement of city quality, park is one of the essential element. The first city park that was made in 1885 is Stijhoff Park. It became a place for European traders to having recreational activities, place for entertainment, and place to eat while listening to the music orchestra $^{5)}$.

Bandung development became much faster because in 1918 there was a plan to move capital of the Dutch East Indies to Bandung and population increase. Many housing built for central government employees ${ }^{6)}$ and city parks also included. In the new development plan Bandung has a concept to become tuinstad (garden city) it is also strongly influenced by city planning theories trend at that time especially Garden City by Ebenezer Howard ${ }^{7)}$. It is shown by many city parks located adjacent with government buildings, schools, and European housing. At that time Bandung has added four more city parks, such as Ijzerman Park, Molukken Park, Insulide Park, and Jubileum Park. Bandung also has several plein (square) such as Tjitarumplein, Tjilakiplein, Oranjeplein, Orchideeplein, Houtmanplein, Limburg Stirumplein, Pandawaplein, Rotgansplein, and Sabangplein ${ }^{3)}$.

After colonial era, the development of parks and squares has been changed. There were several degradations that happened with the previous colonizer's plan. In terms of physical condition, the parks and square in Bandung started to be fenced by local municipality, in condition with lack of maintenance, and turned into illegal parking area. Parks and squares in Bandung also declined in terms of meaning for society. Previously parks and square are public space, center of social activity and then turned into only green space without meaning ${ }^{6}$. Furthermore, Bandung citizen even don't know that parks can be accessible for them and parks has a new meaning as prostitution place. Therefore, we can conclude that there was misconception by local municipality that causing serious degradation for parks and squares in Bandung. 


\section{METHODS}

\subsection{Revitalization of the Bandung Parks and Squares}

In 2013, a new mayor of Bandung Ridwan Kamil sees parks and squares as potentials to reduce or even solve city problems. He also realized the value of public space that can be related with Morales statement that it constitutes the wealth of the cities of the past and they will be the principal structure of the cities of the future. His vision is immensely influenced by his previous background as an architect and urban designer. It marked strong entry of architect into planning and even decision-making arena ${ }^{8)}$. He believes by revitalizing the parks will increase the quality of life in Bandung and people index of happiness. To achieve his vision, He led a massive effort to develop public and open green spaces including parks and squares.

In five years, 30 parks including squares were developed. It attracts various range of interests, from history, skateboard, photography, music, pet owner and so forth. Some were developed in existing parks and squares while the other even created from "dead space" under busy elevated highway. The Mayor created an innovation by providing specific theme in each park. This attempt to attracting more people to come, to give added value of uniqueness to the park and created a space for communities.

To really conceive the effects of revitalization of Bandung Parks and Squares this paper will focus on one main square Alun-alun and one thematic park Pet Park. Alun-alun is chosen because of its meaningful presence for Bandung citizen, while Pet Park is chosen because of strong bond of pet lovers communities with the park.

\subsection{Alun-alun (Central Square) Bandung Revitalization}

Alun alun is indigenous concept of city center that existed before pre-colonial period. The traditional Alun-alun consists of one open square surrounded by four buildings. The buildings are Kraton/ Palace that located in North, market in East, mosque in West, and prison in South. Alun-alun is the symbolic place for the community. During colonial era and after, this concept survived, but still there are degradations from the original concept.

In 2007, the last condition before revitalization, Alun-alun was excavated and twolevel basement was made to accommodate vehicle parking. It is because the city center lacks parking space. It massively changed the physical condition of Alun-alun that previously was multifunctional vast lawn surrounded by big trees. It turned into vast concrete floor with several pots for trees and pool. This design limiting social interaction and lost multifunctional feature. The condition became worst because it has been taken over by informal sectors. The space was taken by many street vendors and became dirty.

In $31^{\text {st }}$ December of 2014, new Alun-alun has been inaugurated. It offers cleaner condition, vast, and more compelling than the previous. The new Alun-alun concept is to optimizing functionality more than former condition. The new is inspired by the basic concept of traditional Alun-alun. It is adapting historical concept but applied in contemporary way. 


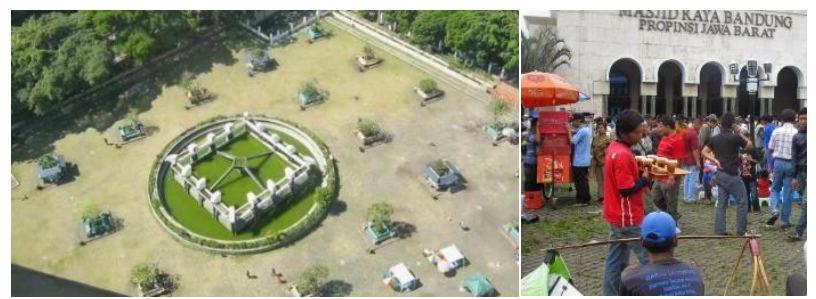

Figure 2: Concrete floor of Alun-alun in 2007 (left); Informal street vendors took over Alun-alun (right) ${ }^{9)}$.

The pots for trees and pool removed from the central part of Alun-alun. Approximately 4.300 sqm of central part of Alun-alun is covered by synthetic grass because of maintenance issue. It has a very interesting green pattern. The orientation of this part also respecting The Great Mosque of West Java Province that located in West. It intended to be extension space for praying during important religious holiday. The physical barrier of different elevation and fences around Alun-alun also removed to create more accessibility for visitors.

At southern park of new Alun-alun, it designed with extruded geometrical form. This form allocated for flowers to grow. Besides its main function as flowers pot, it is also used for creating mini labyrinth. Visitors can play around, take a picture with beautiful flowers, and sit at the edge of the flowers pot. It tended to create a new experience to enjoy Alunalun.

Playground for kids also provided in this new Alun-alun. It located in the northern part. It consists of swings, slider, see saw and so forth. It also has water feature playground that absolutely new for Bandung citizen. It is the most favorite spot for kids to play. This part also has a bus stop to make easy access for visitors.

Public library also provided in the East part of Alun-alun. It provides space for visitors as an alternative for outdoor activity. To gain more knowledge, especially about Bandung from books that provided inside the public library. The purpose of this space also to increase reading interest and reduce number of illiteracies that happen in Bandung.

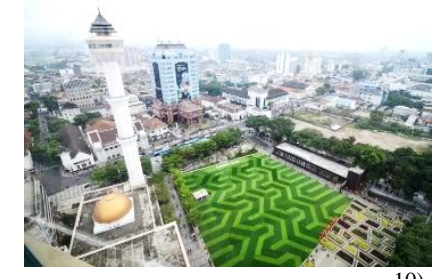

Figure 3: New Alun-alun ${ }^{10)}$

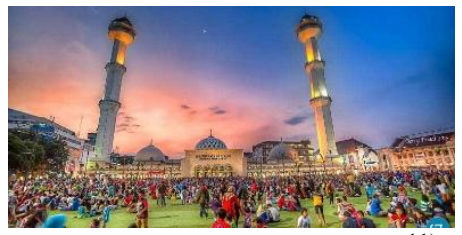

Figure 4: Vast Open Square ${ }^{11)}$. 


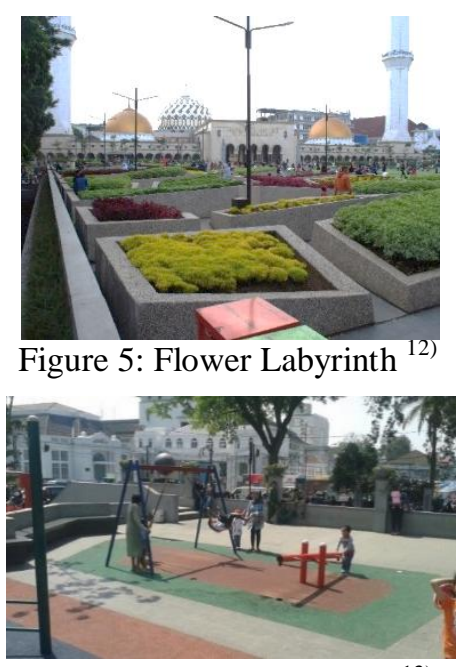

Figure 6: Kids Playground ${ }^{13)}$

Furthermore, the cleaner condition of Alun-alun happens because of efforts by the mayor to regain the conscious of citizen to dispose trash in its place by providing proper trash bin, updating city regulation that related with littering, and massive clean campaign in schools and offices. It is also because the informal street vendors are no longer allowed to occupy the main area that usually contributes to littering in Alun-alun. They relocated in enovated basement area. The renovated basement has well ventilation to access outside fresh air and also let sunlight enter. It is a strategic place for them to sell their goods because they will be the first and the last to see by potential customers who park their car in the basement. It is increasing the opportunity for customer to buying their goods.

\subsection{Park Revitalization: Pet Park Ban}

During colony era, this park is one of part of Tjilakiplein. Tjlakiplein at that time only vast empty meadow. In the middle part of the site there is a man-made river to collect water from surrounding area and to irrigate this plein. After colony era, this park also has similar situation with Alun-alun. It was fenced with poor condition.

Pet park starts with the increasing number of pet lovers communities. They regularly meet in small and big scale. When they meet they usually share experiences and ideas. But the place to accommodate this activity is very rare in Bandung. To tackle this situation, Pet Park was specially built to accommodate animal lovers.

They can bring their pets here and it is not limited to specific animals, pet owners can bring dogs, cats, reptiles, sugar gliders, chicken, and so forth. However, pet owners still need to follow rules when they bring their pets here. The rules are pet owners need to clean pet's poo and pee. Visitors need to check their pet's condition if they sick or not, to make sure they do not spread virus to other pets. Visitors also prohibited to hurt the pets. 


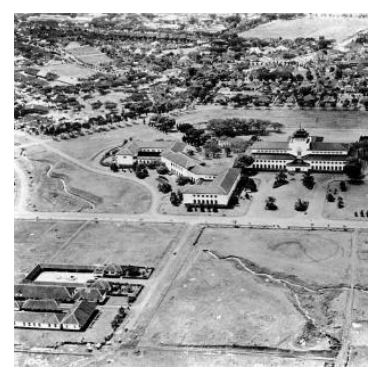

Figure 7: Aerial view of Tjilakiplein ${ }^{14)}$

Total area of this park is $800 \mathrm{sqm}$. The new intervention removed of the fences while still keep some part of it due to keep the animal inside the park and add landscape furnitures. It has several facilities for both people and animals such as park bench, wifi, trash bin, jogging track, and animal playground. To make concept of Pet Park stronger, the landscape furniture designed to looks like animal, for instance, park bench that looks like a rabbit, public cupboard colored white with random black dots to looks like a cow or dalmatian, and statue of human and dogs that represent strong bond between animal and human.

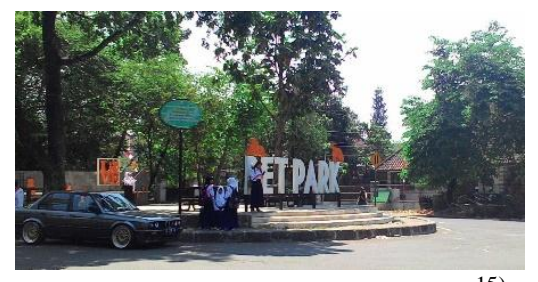

Figure 8: Pet Park entrance area ${ }^{15)}$.
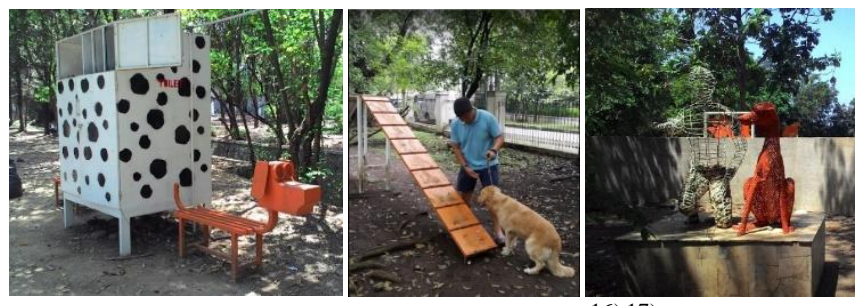

Figure 9: Pet Park Facilities ${ }^{16) 17)}$.

\section{DISCUSSION}

\subsection{Critical Review of the Strategies}

Both projects above have similar approach, it revitalized historical park and square. The new programs are applied by modifying the existing and offering new concept that very contrast with the previous condition. It is transformed and adapted to new context of urban situation that happens in Bandung. Due to its approach, the park (and square) can be seen as palimpsest; one can actually see the layers of design ${ }^{18)}$.

The contrast that proposed from the concept is not come out from nowhere. It derived from the original concept of indigenous traditional square and park during colonial period. It has universal value that can exist and survive without affected by the time. However, it is not trying to be romanticized colonial or traditional by necessarily returned the parks and 
square to previous condition. Because that approach will not be able to match with new urban culture in nowadays society.

Facing the shift in urban culture, the urban project needs to deal with this new condition. According to this, Joan Busquet has explained in his essay several strategies to face new the new urban culture: incorporate new development while respecting their independence, work with context, promoting mixed-use as guarantee of urban quality, highlight the city of the past as fundamental constituent of the present, reinforcing or clarifying the urban morphology of the city, promote densification in urban development, re-establish the relation with natural geography, restructure the existing city, reactivate the city using public space, modulate mobility in urban space, city design have to be multiple, and sustainable city in the mid-term.

Regarding strategies that mentioned above, both projects can be highlighted in several points. First in strategies that works in context. In historical aspect, parks and squares have been part of Bandung city even before colonial era. It means that parks and squares are cannot be separated with Bandung context regardless of the dynamic condition that happened. In nowadays context, both projects shown how it adapt with nowadays context. Alun-alun Bandung now provides playground for kids that very rare because of the scarcity of space in city due to urban development. It also provides public library that responding illiteracy number issue. The vast synthetic grass becomes multifunctional space that can be adjusted for many activities from religious to entertainment for citizen, and so forth. Meanwhile, Pet Park also responding nowadays context especially by providing space for pet lovers communities. Both projects also designed with attractive color and attractive space that really responding to nowadays urban culture that mainly seeks and needs instagrammable place to share in their online social media account.

Second, mixed-use as guarantee of urban quality. Each project has different situation. Alun-alun is clearly fit with this strategy. Because it has vast open space that can be used for any public activities. It also provides several other facilities such as public library, flower pots labyrinth, kids playground, bus stop, commercial space, and basement parking area. Meanwhile, Pet Parks is more focus on providing space for specific communities. It is shown by the park facilities that provided. All the facilities mainly to accommodate pets and their owners, such as animal playground that can be used for dogs to play and practice their ability to follow instructions from the owners, water source and trash bin to clean animal pee and poo, jogging track that mainly use for pet owners to walk or run with their dogs around the park, and benches that mainly use for pet lovers communities to sit and interact with pets or other member.

Third, highlight the city of the past as fundamental constituent of the present. New proposal for both projects not necessarily dictated by the past. It has been contextualized with the nowadays situation and challenges. For instance, original concept of indigenous Alun-alun is a vast open space with grass for multifunctional activities, then the new proposal offering the same idea but using synthetic grass due to the previous basement 
development that turned soil into concrete platform and maintenance cost issue if the space using real grass. The Pet Park still preserve the existing man-made river but then improved with new landscape elements that give new meaning especially for pet lovers communities. Both projects use the information of the past to ensure integration while also considering new context.

Fourth, reactivate the city using public space. Both projects are utilizing the vacant and misuse existing public space. It turned the condition drastically and rejuvenate the concept of park as a tool to increase the quality of life in city. It is shown by the number of visitors that visit both projects. It successfully attracts Bandung citizen to go out from their house and spend their time there especially in weekend. Moreover, it also attracts visitors from other cities that also increase tourism in Bandung, which is good for local economy. The positive effect of social interaction in public space not only for local citizen but also for other tourists that visit both projects.

\subsection{Parks and Square as Urban Acupuncture}

According to both proposals, it is clearly shown that this intervention is considered as urban acupuncture. Because both proposals are part of numerous small scales and very strategic intervention that can obtain large-scale changes and substantial objectives it labeled urban acupuncture based on Berrini's definition. Moreover, from the book Cities of Tomorrow by Peter Hall, urban acupuncture has several characteristics: small-scale interventions, cost trifling amounts of money, that transform a whole area of the city and enhance the city image as a whole.

Based on the character of urban acupuncture, in terms of scale, the intervention not really taking enormous space. It is only taking the existing park and square space that scattered within Bandung city. From those scattered space can generate and enable greater impact. It is shown that both projects can attract Bandung citizen even visitors from outside Bandung city to spend their time there.

From cost aspect, both projects considered as low cost but high value for the city. According to head of Bandung Cemetery Garden Office, revitalization for Pet Park spent 190 million rupiah (Approximately 11 thousand euro). Meanwhile, for Alun-alun it cost 10 billion rupiah (approximately 600 thousand euro). It considered cheap expenses compared to the benefit from tourism, social health, happiness index, and many other positive effects that come after.

As images of the city, both projects truly give big contribution to improving the image of Bandung city. Bandung in the past was well known as city of flowers. It is because of images Bandung of the past has many parks with beautiful flowers. But then it degraded. Both projects help to revive the past image of Bandung. 


\subsection{Alun-alun and Pet Park as Public Space}

The role of parks and squares as public space to increase quality of life in urban context has been recognized since colonial period in Bandung. Besides of its importance for the environments, it is also has a psychological and social service. It is very significant for the livability and well-being of citizen in cities. It can reduce stress ${ }^{19)}$. It is also can increase index of happiness through social interaction that happens in public space ${ }^{20}$.

Ridwan Kamil uses the new paradigm of index happiness to measure the success of public space intervention. In one of interview he said, "What we've done are small-scale interventions, but they can improve citizen's moods, connect people to places and improve mental health," he added. "We've seen a slight increase in the Happiness Index since we developed the parks. This fact also approved by research that value of people happiness index reached 70.6 in 2015. That amount increased 2 points from the previous in $2013^{21}$.

The intervention of Alun-alun and Pet Park recover its function as public space. During weekday, Alun-alun always crowded in the afternoon. This place is a favorite place to rest and relax for many people. It is dominated by office workers around and kids from school near Alun-alun. In the weekend, people come from many places, it is dominated by family who also bring their kids to play in Alun-alun. It also becomes favorite place for domestic and foreign tourists who visit Bandung.

Pet Park has a different condition. Although it intended to be public space, but thematic concept makes this space less crowded compared to Alun-alun. Because the visitors will be automatically filtered and dominantly only attract people who have specific interest in this case is pets. Nevertheless, this situation is already predicted and by design. Thematic concept was given to create variety and give unique character to each park intervention. It is also intended to give more sense of belonging to specific community. By having sense of belonging, it hoped that the community will maintain the park and to make it more sustainable.

In real condition, pet lovers communities have a contribution to maintain the Pet Park. It is shown by the routine activity to clean the park. The serious commitment also shown by an organization that organizes many pet communities and events or activity for Pet Park. In the end, community of Pet Park is helping the city government by also contribute to maintaining the park. However, the organization is not active since 2017, the role of coordinator is no longer exist, but the pet communities still maintain the park only eventually not routinely.

Besides the positive effects, there are also negative effects that caused by the new intervention. In Pet Park, there is no parking space strategy in the new interventions. This condition frequently increasing traffic congestion when communities held an event or during peak hour of visitors. This situation happens in most of new parks. 


\section{CONCLUSION}

Revitalizing parks and squares are one of the efforts by the mayor to make Bandung city not only livable but also lovable. Both two projects example are great and successful urban intervention. Those interventions successfully revive the glory of parks and squares in the past to increase the quality of life in city. The index of happiness also introduced as a new tool to measure the success of public space interventions. And the results are positive based on the increase number of people index of happiness in Bandung.

Both projects also success to adapt with the new urban culture in Bandung. Strategy criteria by Peter Hall is used to measure the success. Both projects use the strategy of works in context, mixed use as guarantee of urban quality, highlight the city of the past as fundamental constituent of the present, and reactivate the city using public space.

Alun-alun and Pet Park are great examples of urban acupuncture. In terms of scale, both projects only scattered piece of space as a remnant due to urban development within the city. From cost value, it is considered cheaper than the economic benefit that obtained after its completion. It also contributes to bring back the pleasant images of Bandung as flower city and livable with nowadays context.

As public space, both projects are successfully work. After having degradation for several decades, the new interventions are able to recover the condition. It is also offering fresh concept that shows contemporary way dealing with context and not necessarily dictated by the glory of the past. Nevertheless, it is still respecting the indigenous original concept that becomes base for the latest intervention.

The new intervention also considering the potential of communities that exist in Bandung. This potential is considered by the mayor as a key of success for public spaces. It is used by mayor to create relationship between municipality and communities. Top down and bottom up strategy combined in terms of municipality collaborate with communities for the thematic parks. Involving communities in thematic parks can help the role of municipality to maintain the parks. In economy aspect, this approach can reduce the cost for maintenance. Communities also will help to make parks more sustain by their routine activities. Although this approach still has disadvantages, in terms of making the parks only attractive for specific communities and limiting the visitor. In addition, it is also important to maintain the regeneration of community organization that responsible for the park, because at some point the organization can be dismissed or inactive. It is still a challenge for municipality to maintain not only the parks but also the communities.

\section{REFERENCE}

1) Maulana, Suhardi. "Seremban Urban Park, Malaysia: A Preference Study." Master thesis, Blacksburg: College of Architecture and Urban Study, 2002.

2) Hardjasaputra, Sobana. "Perubahan Sosial di Bandung 1810-1906." PhD diss., University of Indonesia, 2002

3) Kunto, Haryoto. Wajah Bandoeng Tempo Doloe. Bandung: Granesia, 1984. 
4) Pieterspark te Bandoeng. Before 1930. Digital Image. Pinterest. Accessed January $7^{\text {th }}$, 2019. https://id.pinterest.com/pin/835558537093844775/?p=true

5) Kunto, Haryoto. Balai Agung Kota Bandung. Bandung: Granesia, 1984

6) Dienaputra, Reiza. (2004). Bandung 1906-1970; Studi tentang Perkembangan Ekonomi Kota, presented at The $1^{\text {st }}$ International Conference on Urban History, Surabaya, 23-25 August.

7) Fireza, Doni, Kajian Pola Ruang Terbuka di Kota bandung: Sebuah Produk Budaya akibat Perkembangan Jaman." Ruanghijau. December $1^{\text {st }}$, 2008. Accessed January $3^{\text {rd }}$, 2019. https://ruanghijau.wordpress.com/2008/12/01/kajian-pola-ruang-terbuka-dikota-bandung-sebuah-produk-budaya-akibat-perkembangan-jaman/

8) Hall, Peter. Cities of tomorrow: an intellectual history of urban planning and design in the twentieth century. Oxford, UK: Blackwell Publishers, 1996.

9) Harsindo, "Detik Tempo Dulu:Foto-foto Alun-alun Bandung Tempo Doeloe dan Sekarang." Blogdetikblog. June $18^{\text {th }}, 2017$. Accessed January $4^{\text {th }}, 2019$. https://blogdetikblog.wordpress.com/2017/06/18/detik-tempo-dulufoto-foto-alunalun-bandung-tempo-doeloe-dan-sekarang/

10) Taman Alun-alun Bandung. Digital Image. Inews. Accessed January $7^{\text {th }}, 2019$. https://www.inews.id/multimedia/read/254409/begini-wajah-baru-taman-alun-alunbandung-setelah-direvitalisasi

11) Alun-alun Kota Bandung. Digital Image. Segalainfo. Accessed January $6^{\text {th }}, 2019$. http://segalainfo.com/alun-alun-kota-bandung/

12) Taman tanaman hias. Digital Image. imaruphadhatuunermalang. Accessed January $7^{\text {th }}$, 2019. https://imarupadhatuunmermalang.wordpress.com/2016/03/06/alun-alun-kotabandung-2/

13) LET'S PLAY OUTSIDE! - PLAYGROUND TAMAN ALUN-ALUN BANDUNG. Digital Image. itsmellslikecoffee. Accessed January $7^{\text {th }}, 2019$. http://itsmellslikecoffee.blogspot.com/2015/11/lets-play-outside-playground-tamanalun.html

14) Tjilakiplein. Digital Image. Mooi Bandoeng. Instagram. Accessed January $7^{\text {th }}, 2019$. https://www.instagram.com/p/BcW8MySAFF1/

15) Nururrohmah, Zainab \& Suhirman, "Shared-power governance in managing common pool resources case study: collaborative planning to manage thematic parks in Bandung City, Indonesia." Procedia - Social and Behavioral Sciences Vol. 227 (July 2016). 456-476.

16) Nururrohmah, Zainab \& Suhirman, "Shared-power governance in managing common pool resources case study: collaborative planning to manage thematic parks in Bandung City, Indonesia.” Procedia - Social and Behavioral Sciences Vol. 227 (July 2016). 456-476.

17) Pet Park. Digital Image. Google. Accessed January $7^{\text {th }}, 2019$. https://www.google.com/maps/place/Pet+Park/@ 6.9049433,107.6267693,3a,75y,90t/data=!3m8!1e2!3m6!1sAF1QipNdlm2YoChkeE2 
Xpi4eXNcA8k_wW_xDqaQFAVRX!2e10!3e12!6shttps:\%2F\%2Flh5.googleusercont ent.com\%2Fp\%2FAF1QipNdlm2YoChkeE2Xpi4eXNcA8k_wW_xDqaQFAVRX\%3 Dw180-h120-kno!7i6000!8i4000!4m5!3m4!1s0x2e68e7b5da473503:0xd077be7506c5c62c!8m2!3d$6.9049573 ! 4 \mathrm{~d} 107.6267815$.

18) Czerniak, Julia, and George Hargreaves. Large Parks. New York, NY: Princeton Architectural Press, 2008

19) Ulrich, R.S. "Natural Versus Urban Sciences: Some Psycho-physiological Effects." Environ. Behav. Vol. 13 No. 1 (1981). 523-556.

20) Markman, Art, "Does the Quantity of Social Interactions Affect Happiness?" Psychology Today. October $1^{\text {st }}$, 2018. Accessed January $5^{\text {th }}, 2019$. https://www.psychologytoday.com/intl/blog/ulterior-motives/201810/does-thequantity-social-interactions-affect-happiness

21) Maulana, Arief, "Residents Happiness Index Increase Needs To Be Accompanied By Cultural Values Implementation." Unpad. December $9^{\text {th }}$, 2016. Accessed December $30^{\text {th }}$, 2018. http://www.unpad.ac.id/en/2016/12/peningkatan-indeks-kebahagiaanwarga-perlu-disertai-penanaman-nilai-kultural/ 